\title{
Problems of the Growth of the External Public Debt of the Kyrgyz Republic
}

\author{
CHOLPON TOKTOSUNOVA*1, NURMIRA SHARSHEEVA², GULNAZ ABDUKADYROVA ${ }^{3}$, \\ NAZGUL RASULOVA ${ }^{4}$, SAIKAL ESENAMANOVA ${ }^{5}$ \\ ${ }^{1,2}$ Department of Finance and financial technologies named by S. Sulaimanbekov, KYRGYZ ECONOMIC \\ UNIVERSITY NAMED BY M. RYSKULBEKOV, BISHKEK, KYRGYZSTAN. *E-mail: cholpon75@mail.ru \\ ${ }^{3}$ Department of Banking and Securities Market, KYRGYZ ECONOMIC UNIVERSITY NAMED BY M. RYSKULBEKOV, \\ BISHKEK, KYRGYZSTAN. \\ ${ }^{4}$ Department of Quality and Accreditation, KYRGYZ ECONOMIC UNIVERSITY NAMED BY M. RYSKULBEKOV, \\ BISHKEK, KYRGYZSTAN. \\ ${ }^{5}$ Department of Economics and Foreign Economic Activity, KYRGYZ ECONOMIC UNIVERSITY NAMED BY M. \\ RYSKULBEKOV, BISHKEK, KYRGYZSTAN.
}

\begin{abstract}
The problems of the growth of public debt affect an increasing number of states in the modern world. Most countries record a significant shortage of their resources when making domestic investments and cover the state budget deficit and carry out socio-economic transformations. This lack of funds led to the formation of an economic debt system. At the same time, with the liberalization and globalization of financial markets, there will be an increase in the dependence of national economies on external replenishment. When carrying out economic transformations, most of the modern world countries resort to using external and internal sources of financing.

The Kyrgyz Republic is no exception to this rule and today is largely dependent on external funding from foreign donors. At the same time, the lack of a consistent policy in attracting and using external and internal financial resources has led to the formation of significant external debt, which does not allow for economic transformations to ensure the country's economic security. As a result of this study, recommendations were formed for the Ministry of Finance of the Kyrgyz Republic, which proposes a balanced policy of attracting expensive foreign loans to reduce the debt burden. In this study, the principles of dialectical logic, the unity of the logical and the historical, and generally scientific methods of cognition were used. Analysis, synthesis, consistency, special comparisons, groupings, classifications, generalization can be distinguished.
\end{abstract}

Keywords: Public external debt, investments, international creditors, foreign loans

JEL Classification: P43, H63, H81, G18 


\section{Introduction.}

At the moment, there is insufficient knowledge of the problem of stable growth of public debt, there is a lack of a comprehensive analysis of this problem, and the current state and all issues of debt management do not correspond to the previously developed strategic programs. Here it is worth realizing that a competition policy in settlement of public debt is a national security factor. It will make it possible to protect ourselves from the impact of our international creditors, which will allow us to engage in independent foreign and domestic policies. Thus, the study of public debt problems is relevant since most of the available monetary receipts of the republic are formed from external or internal borrowings.

The study's primary purpose is to analyze the formation of public debt and the characteristics of its impact on the economy. In order to achieve this goal, it is necessary to solve the following tasks: conduct a comprehensive study of the main stages of the formation and growth of the public debt of the Kyrgyz Republic, identify the main problems in the functioning of the budget mechanism and servicing the public external debt.

\section{Historical preconditions for the emergence of public debt.}

The main reason for the formation of external debt of the Kyrgyz Republic is loaning after 1991 and the debt of the USSR, which the Russian government took over [1], [2]. It is rather difficult to establish the exact amount of the USSR's debt since, in the post-war years, the country was an exemplary borrower who fulfilled its debt obligations on time and in full. However, the loan amounts were different from the modern ones. True, in 1984, there was a significant jump in debt since more than 15 billion US dollars were employed in the foreign market, which already amounted to about $5 \%$ of the GNP. By 1986, the size of foreign loans had reached $\$ 30$ billion, which was $50 \%$ of exports, and in 1989 it had grown to $\$ 50$ billion [3].

It is worth noting that most of the countries of the Soviet Union if you do not take into account the Russian Federation, did not have experience in attracting foreign loans and borrowings until 1992. At the time of the implementation of all market reforms, the Kyrgyz Republic was only establishing legal, administrative and institutional norms for external financing. Such underdevelopment of this system led to the fact that the external debt of the Kyrgyz Republic from 1992 to 1999 increased 45 times from $\$ 36.41$ million to $\$ 1,622.12$ million. A similar situation was observed with external debt in other developing countries of the CIS [4].

An active policy in carrying out reforms began with the acquisition of independence [5], [6]. The republic started to take decisive steps in carrying out reforms aimed at a full-fledged transition to a market economy. At the initial stage, all reforms were carried out in the wake of highly negative processes, when financial subsidies from the Union budget, which until 1991 amounted to $11 \%$ of GDP, were stopped entirely. Also, among the negative factors, it is worth noting the collapse of the interstate system of division of labor, the rupture of economic ties between enterprises. It led to a sharp decline in production, a significant decrease in the standard of living of the population, an increase in unemployment and an increase in the level of migration of the people [7].

Another severe problem was the lack of sufficient experience in attracting external borrowings. It is worth noting that most of the countries of the Soviet Union if you do not take into account the Russian Federation, did not have experience in attracting foreign loans and borrowings until 1992 [8].

At that time, the Kyrgyz Republic was just beginning to establish legal, administrative and institutional rules for external financing. Over ten years (1992-2002), the gross external debt of the Kyrgyz Republic increased from USD 36.41 million to USD 1920.19 million, i.e. almost 53 times. This state of external debt has developed mainly as a result of the following reasons specific only to the CIS countries, as well as a result of reasons typical for other developing countries [9].

After the collapse of the USSR, the balance of payments was upset and difficulties arose in the supply of material and technical resources between the republics. 
Under these conditions, to improve the financial situation of certain sectors of the national economy of the republic, which has developed as a result of continuing inflationary processes, a decline in production and the rupture of inter-economic ties, the Government of the Kyrgyz Republic was forced to take significant loans from other countries and international organizations.

Although the Kyrgyz Republic's debt portfolio was considered small at the time (compared to other $\mathrm{CIS}$ republics), foreign borrowing continued to grow. Since then, the priority task for Kyrgyzstan has been the need to mobilize resources from all possible sources to maintain the vital (critical) level of imports and prevent a decline in production [8].

In order to prepare the economy to a level at which it can realize vast flows of investment effectively, it was necessary to create the appropriate conditions for the normal functioning of market mechanisms. This creation of conditions was possible only through a series of large-scale structural reforms, including privatization, reforms in agriculture, the financial sector, reforms in the legal and regulatory sphere, etc. Such structural reforms were financed by many international financial institutions (IMF, World Bank, European Bank for Reconstruction and Development, Asian Development Bank, Islamic Development Bank) and donor countries (Japan, Germany). Among the structural reform and rehabilitation programs financed with World Bank loans, the most prominent is the Enterprise Sector Privatization and Reform Program (the US \$ 60 million). More than 140 stateowned enterprises were corporatized due to the implementation of this Program.

At the stage of 1992-1995, when the Kyrgyz Republic experienced an acute economic crisis, during the painful process of transition to market conditions of management, the question was about the survival of the economy. Foreign loans were directed mainly to support the critical level of imports and cover the budget deficit. For example, the share of financing the budget deficit from external sources for 1992-1997 increased significantly, amounting to 86\% in 1997 compared to 1992, when this share was $32 \%$.

The absence of external debt to non-CIS countries, the relative political stability in the republic and the course taken to develop a market economy served as good prerequisites for attracting foreign loans to the Kyrgyz Republic. Therefore, the accession of Kyrgyzstan to the IMF and other international financial institutions practically became the beginning of attracting foreign investment to the Kyrgyz Republic.

Kyrgyzstan accepted membership in the IMF in 1992. The Kyrgyz Republic has purchased funds under stand-by agreements and a structural adjustment program. At the beginning of 1996, the liabilities amounted to SDR 43.9 million. As a result of the approval in 1994 by the IMF Executive Board of a three-year program of the Expanded Structural Change Facility (EIFF), a decision was made to provide a loan in the amount of SDR 88.2 million. This program was accepted for implementation and continued in 1996. As of January 1, 1997, the drawdown for this funding program amounted to SDR 55.9 million. The balance of SDR 32.3 million was financed in 1997.

The World Bank, of which the Kyrgyz Republic also became a member in 1992, continues to provide active assistance to the republic by financing many projects. The projects are mainly focused on programs for developing infrastructure, private entrepreneurship, financial and agricultural sectors. These are such projects as PESAK (Program for reorganization and liquidation of unprofitable enterprises), FINSAC (Program for reorganizing the banking system), APEAC (Program for the development of the agricultural sector), the project for the reconstruction of the Bishkek-Osh highway, etc.

With the formation of independent states, the membership of the USSR in the European Bank for Reconstruction and Development (EBRD) was automatically transferred to the Kyrgyz Republic with a certain amount of a shared contribution. Currently, cooperation with this international institution is expressed in financing or co-financing with other multilateral organizations of various projects in the Kyrgyz Republic. One of the first projects co-financed by the EBRD with the World Bank is the US \$ 9.4 million TELECOM project. In 1995, the European Bank for Reconstruction and Development 
began financing a project to develop a power transmission network in the amount of US $\$ 38.0$ million. The actual amount of the loan in 1999 was the US $\$ 37.19$ million.

\section{The current state of public debt.}

Today, for Kyrgyzstan, foreign borrowing remains the main source of funding for measures of primary need:

- support for the national currency;

- covering the budget deficit;

- implementation of structural reforms in almost all sectors of the economy;

- financing investment projects to prevent a decline in production and help to revive the economy.

Foreign loans provided to the Kyrgyz Republic can be divided into:

- program loans - aimed at financing and structural transformation of several sectors of the republic's economy;

- project loans - aimed at financing a separate investment project in a particular sector of the economy.

The primary purpose of using foreign loans is long-term lending for investment activities of enterprises in priority sectors of the republic's economy and covering the budget deficit.

Most of the public debt consists of external assistance to Kyrgyzstan, provided in the form of the following grants:

1. The bulk of external grants is currently being channeled through technical assistance projects, including expertise, training, equipment and funding for the management of the assisted program. The donor agency usually coordinates such assistance. Information on project financing is not always mandatory to the government (this makes planning and tracking disbursements for technical assistance projects challenging). As a result, grant-financed technical assistance has been excluded from the PIP, although it often serves as an investment function in supporting institutional development and reform.

2. Kyrgyzstan also continues to receive external assistance through grants in equipment and consumer goods such as medicines, mainly through humanitarian aid programs. These types of assistance are usually short-term and quickly deployed. These types of assistance do not meet the criteria for inclusion in the PIP.

3. A relatively small proportion of aid, in the form of grants, is truly investment financing, managed with the direct involvement of Kyrgyzstan. This funding is included in the PIP.

All donors in the Kyrgyz Republic can be conditionally divided into two categories:

1. Multilateral international organizations (40\% of all funds provided to Kyrgyzstan): World Bank, International Monetary Fund (IMF), Asian Development Bank (ADB), European Bank for Reconstruction and Development (EBRD), European Union (EU), Islamic Development Bank (IDB), the Eurasian Development Bank (EDB) and some other organizations.

2. Governments of foreign countries (60\% of all funds): China, Russia, Japan, Switzerland, Germany, USA, Great Britain, Turkey, Denmark, the Netherlands and some others.

The largest multilateral donors of the Kyrgyz Republic are ADB, WB, IMF, EBRD and bilateral donor countries such as China, Japan, Germany, Turkey, Russia and others.

For the thirtieth year, the Kyrgyz Republic has existed and is developing as an independent and sovereign state, carrying out democratic transformations and transitioning to market relations. In the present conditions, the state debt has moved to the center of the country's economic problems, which requires the closest attention to this economic category and the issues associated with it. 
Since gaining independence, the Kyrgyz Republic has accumulated a significant amount of foreign debt that it cannot service. It is a paradox since the Kyrgyz Republic began the transition period without any external debt at all.

In order to prepare the economy to a level at which it can realize vast flows of investment effectively, it was necessary to create the appropriate conditions for the normal functioning of market mechanisms. This creation of conditions was possible only through large-scale structural reforms, including privatization, reforms in agriculture, the financial sector, the legal and regulatory sphere, etc.

Since Russia assumed the share of Kyrgyzstan in the external debt of the former Soviet Union and its obligations to service it, Kyrgyzstan by the end of 1992 had practically no debt in convertible currency. Most of the loan agreements concluded in 1992, including agreements with the European Union and Turkey, remained essentially unfulfilled. As of November 3, 2000, the volume of foreign loans signed by the Government of the Kyrgyz Republic amounted to USD 1,856.35 million, including from the CIS countries - $\mathbf{2 5 7 . 4 6}$ million US dollars, from non-CIS countries and international financial organizations - 1598.89 million US dollars. Of these, 1362.21 million US dollars were received. For 1992-2000, payments were made in 208.17 million US dollars, including the principal amount of 110.09 million US dollars (for loans from Uzbekistan, Switzerland, China, Turkey, Islamic Development Bank, Germany), on interest - USD 98.08 million [4].

The republic attracted foreign loans and credits over the years of reforms for the implementation of the following goals, interrelated with each other:

- support of the national currency and balance of payments;

- financing critical public sector imports and government budget deficits;

- structural transformations, implementation of measures of economic reforms in all sectors of the economy;

- rationalization, development and strengthening of the social protection and health care systems;

- investment projects aimed at modernizing existing and creating new efficient industries in the republic.

Loans received from international financial institutions and donor countries are provided on preferential terms (maturities from 15 to 40 years, grace periods from 5 to 10 years, interest rates from 0.75 to $3 \%$ ). Significant creditors of Kyrgyzstan are the World Bank, the International Monetary Fund, the Asian Development Bank, the European Bank for Development and Reconstruction, the governments of Japan, Turkey and Germany. Their loans account for $93 \%$ of all assistance provided to the Kyrgyz Republic, including $54 \%$ provided by the World Bank and the International Monetary Fund. Loans received through the World Bank and the International Monetary Fund are the cheapest (from $0.5 \%$ to $0.75 \%$ per annum for $30-40$ years with a grace period of 10 years). These loans aim to structural changes in the economy, supporting the national currency and balance of payments.

To solve the problems of repayment, the State Debt Repayment Fund was created within the state budget of the republic. The Jogorku Kenesh determines the sources of creation and execution of the fund for repayment of the state debt of the Kyrgyz Republic.

\section{Statistics of foreign credits and loans.}

If we sum up all foreign loans for today, then we get about 4.5 billion dollars, and this amount is approaching the critical threshold of $60 \%$ of GDP. The volume of external debt of Kyrgyzstan is also growing due to the growth of the dollar. Because Kyrgyzstan takes loans in American currency, it pays off by buying dollars on the domestic market.

In 2019, the size of the public debt of the Kyrgyz Republic amounted to USD 4,587.26 million (KGS $319,474.64$ million), of which: $83.9 \%$ is public external debt: USD 3850.73 million (268,179.79 million soms); $16.1 \%$ is the internal state debt: 736.53 million US dollars (51 294.85 million soms). According 
to preliminary data, the ratio of the public external debt of the Kyrgyz Republic to GDP for 2019 was 45.5\%. Total public debt (external + internal) to GDP in 2019 amounted to 54.1\% (Figure 1) [4].

Figure 1. The public debt of the Kyrgyz Republic for 2015-2019

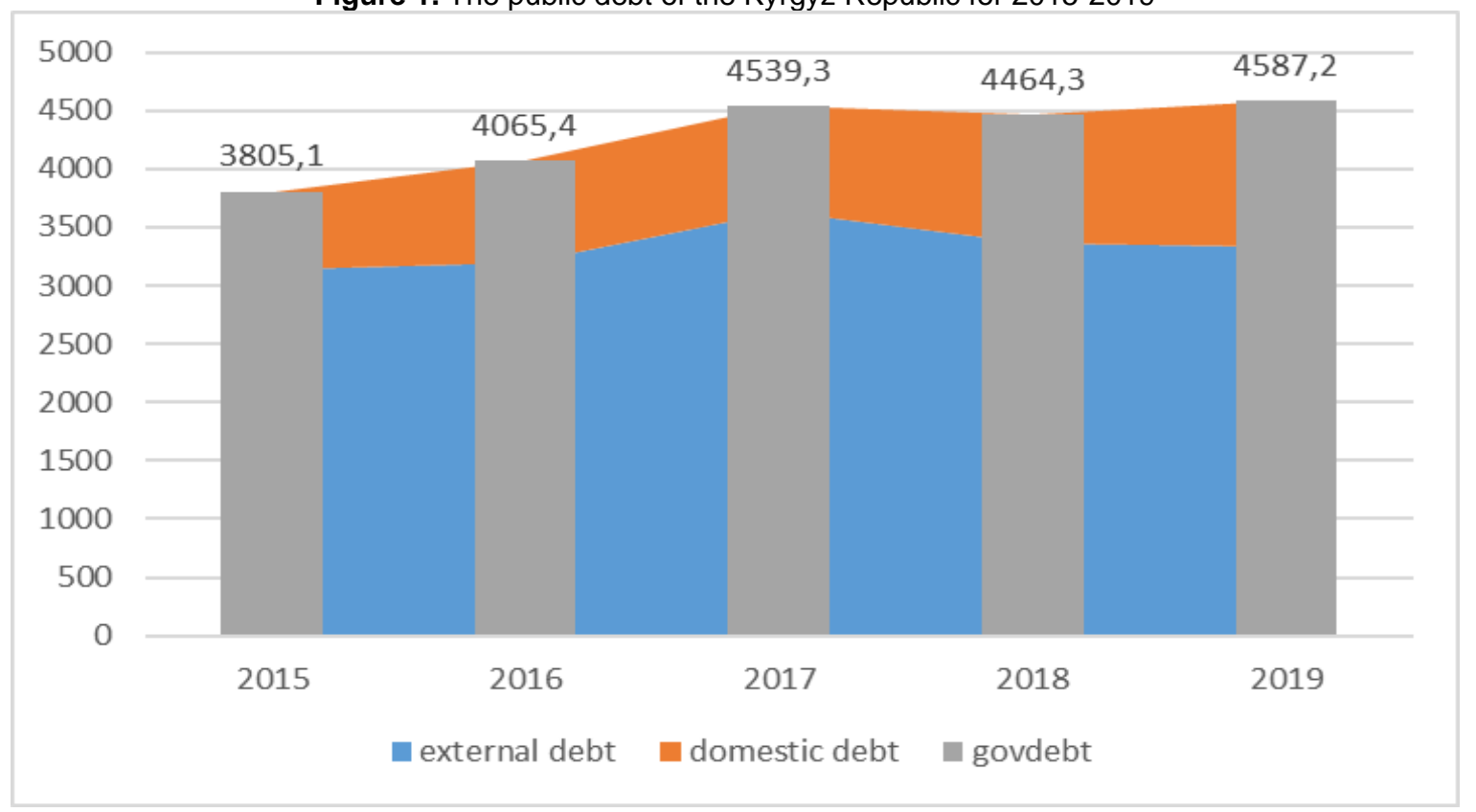

As Figure 1 shows, Kyrgyzstan's external debt on bilateral non-concessional loans fell from $\$ 250$ million in 2015 to $\$ 8.15$ million in 2019. At the same time, debts on concessional bilateral loans for the same period doubled - from $\$ 1.32$ billion to $\$ 2.2$ billion. As of December 31, 2020, the size of the public debt (external + internal) of the Kyrgyz Republic amounted to 4,925.81 million US dollars $(407,116.82$ million soms), of which: $85.6 \%$ is public external debt: $4,217.45$ million US dollars (348,571.15 million soms).

Figure 2 shows that most loans were multilateral concessional loans until 2014, and from 2014 until 2019, unilateral concessional loans began to dominate [4].

Figure 2. Public external debt of the Kyrgyz Republic by types of loans (from 2009 to 2019)

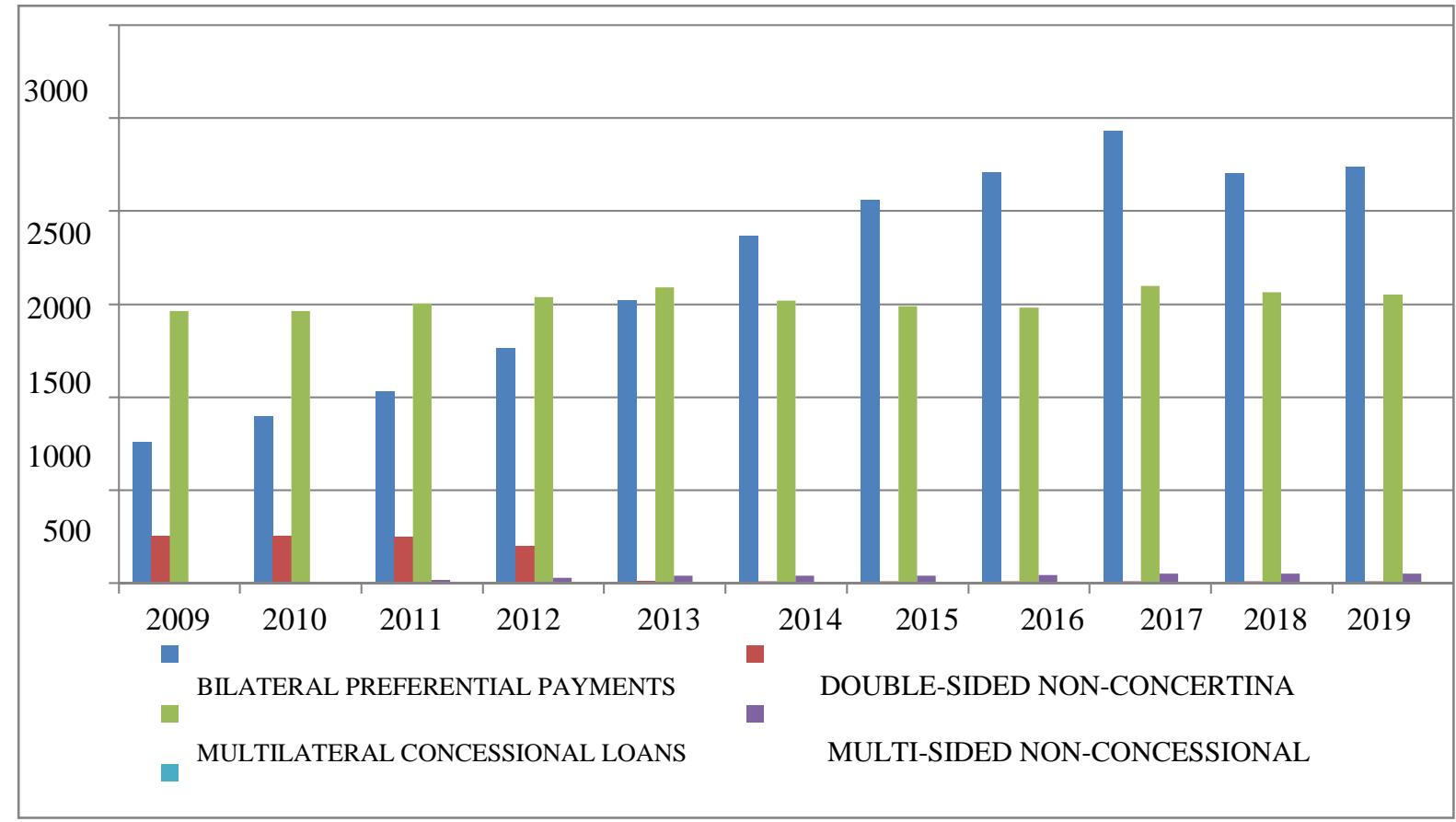


Each Kyrgyz citizen accounts for more than USD 700 of the country's external debt. Grant and credit flow for the Kyrgyz Republic is practically inexhaustible. Funds have come and will continue to come from various donors to our country. However, improvements are noticeable only in the development of democracy, the construction and reconstruction of roads, and the construction of new energy facilities. There is no large-scale construction of schools, hospitals and other socially significant facilities.

Loans were taken mainly for infrastructure projects: constructing an alternative North-South highway, the construction of the "Datka" substation, and the reconstruction of a thermal power station. Infrastructure projects indeed have a positive effect on the economy, but indirectly. But there is no need to talk about the diversification of the economy, its self-sufficiency.

The Export-Import Bank of China has become the most significant bilateral preferential lender since 2014 (Figure 3).

Gradually, Kyrgyzstan approaches the threshold of external debt, when it will have to pay off with entirely accurate resources.

For example, Tajikistan's debt to China is $\$ 1.2$ billion. As of today, it is known that Dushanbe transferred the Upper Kumarg gold deposit in the Sughd region to the Chinese company TBEA to repay the debt. Naturally, this circumstance is very, very alarming for the Kyrgyz public.

Figure 3. Dynamics of received bilateral soft loans

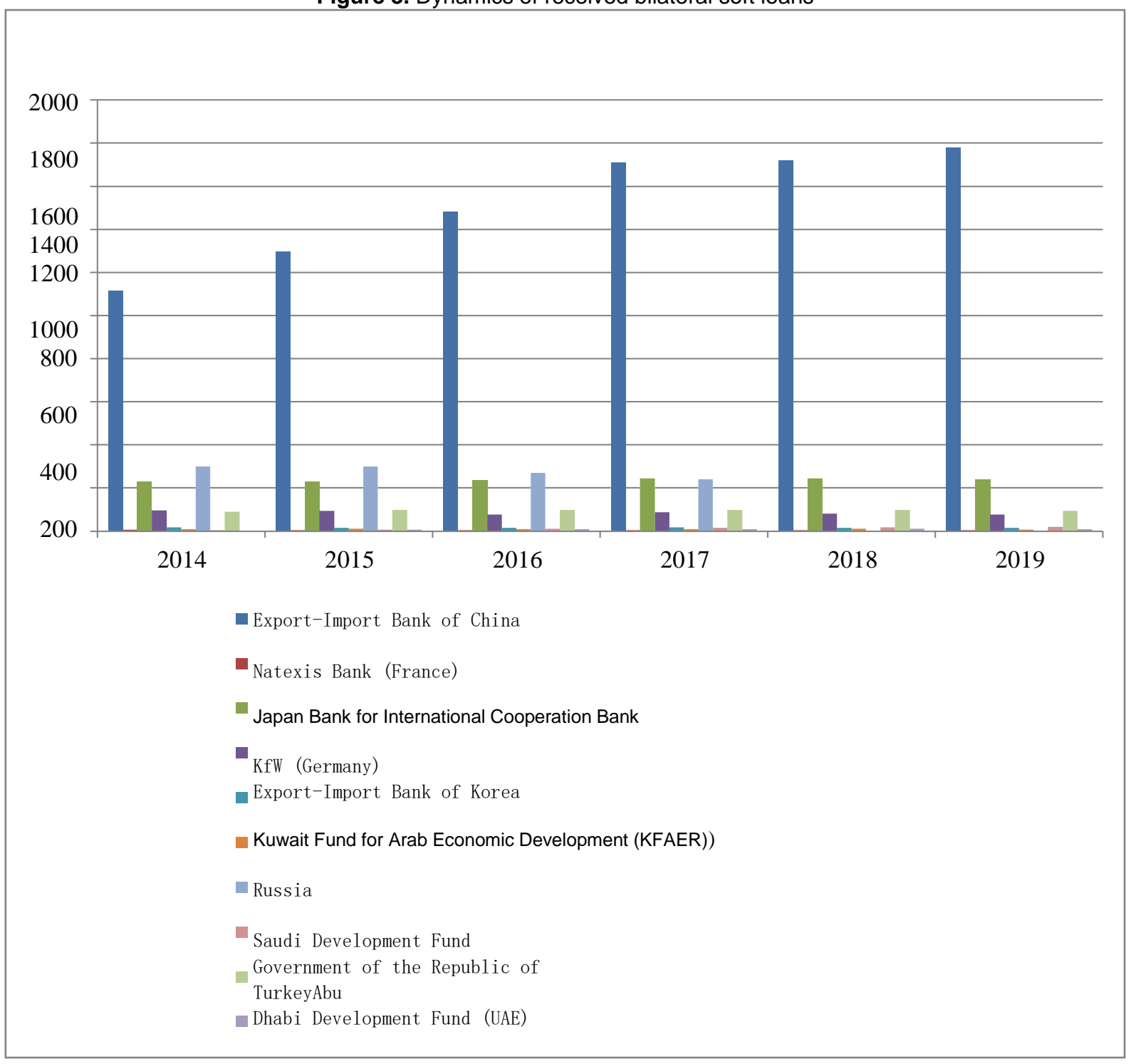


When talking about Chinese loans, it is essential to understand that the international aid architecture includes the traditional North (developed countries). South (developing countries) model and a relatively new model of South-South cooperation, where official development assistance comes from the more developed countries of the global South, united within the BRICS (India, China, Russia, Brazil and South Africa).

But the problem is that if traditional development partners are ready to accept the above agreements on aid effectiveness, then the global South is not ready.

In particular, China does not intend to follow the agreements on aid effectiveness and development effectiveness, arguing that China, unlike traditional donors, is still a developing country. Therefore, it will follow its principles of providing official aid to countries. And, indeed, a particularly criticized part of the Chinese line of assistance in Kyrgyzstan is that the republic is obliged to buy Chinese raw materials with Chinese loans, to attract Chinese citizens for work.

For the period 1992-2019, Kyrgyzstan received about 3792.64 billion US dollars, of which 1.7 billion US dollars accounted for China, while a sharp jump was observed during the presidency of $A$. Atambaev (Table 1).

Table 1. Dynamics of growth of the public debt of Kyrgyzstan to China, million USD

\begin{tabular}{|c|c|c|c|c|c|c|c|c|c|c|c|}
\hline LENDER & 1992 & 1997 & 1998 & 2000 & 2005 & 2010 & 2016 & 2017 & 2018 & 2019 & 2020 \\
\hline 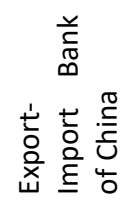 & 4,97 & 3,43 & 2,29 & - & 13,94 & 150,95 & $1.482,83$ & $1.708,13$ & $1.719,38$ & 1778,51 & $1.766,00$ \\
\hline 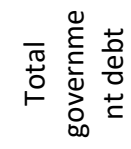 & 4,97 & 875,55 & $1.099,20$ & $1.396,35$ & $1.882,23$ & $2.615,67$ & $3.742,74$ & $4.089,83$ & $3.825,75$ & $3.850,73$ & $4.217,45$ \\
\hline
\end{tabular}

If in 2011 Kyrgyzstan owed him only $\$ 272$ million, then in 2019, this amount increased sixfold to $\$$ 1 billion 778 million. Debts to the Bank of Japan decreased from USD 357 million (2011) to USD 239 million. Debts on concessional multilateral loans moved upward - if in 2011 they amounted to 1 billion 503.9 million US dollars, then in 2019 they amounted to 1 billion 550.13 million US dollars - a difference of 46.23 million. Debts on non-concessional multilateral loans in 2019 amounted to US \$ 50.7 million. In 2014, this amount was US $\$ 40.6$ million, an increase of US \$ 10 million [11].

From year to year, Kyrgyzstan becomes theoretically sovereign, but in fact, it acquires the status of an "economic slave" more and more, sinking more and more into the "swamp" of debts. The reason for such a deplorable socio-economic state was the weakness of state management and dependence on foreign "benefactors" and several other, both economic and political factors.

In general, over the period from 1992 to 2019, more than 300 loan and grant agreements were signed with international financial institutions (IFIs) and donor countries. The largest multilateral donors of the Kyrgyz Republic are ADB, WB, ISDB, EBRD and bilateral donor countries such as Japan, Germany, China and others.

The public external debt consists of more than 200 international loans, most of which (over 98\%) were provided on concessional terms with an interest rate of 0.75 to $2.0 \%$ and a maturity of up to 40 years. External loans, except 33 loans from the European Bank for Reconstruction and Development (EBRD), are provided at a fixed interest rate.

The largest creditors of Kyrgyzstan are China, the International Development Association (IDA) and the Asian Development Bank (ADB), representing $77 \%$ of the total public external debt portfolio. Japan and the IMF follow this with 7 and 5 percent, respectively. 
The external debt of the Kyrgyz Republic is as large as ineffective. The country took loans, not for serious diversification of the economy but unrelated, disparate projects. Sources that bring real income to the state treasury have not been created. Accordingly, interest payments will be due to cuts in spending on education, health care, etc.

The state can and should borrow on normal, natural and reasonable bases and conditions. Normal debt is real evidence of trust in the state on creditors, both individuals and legal entities. In practice, in an efficient, normally developing, stable economy, public debt is not a key problem in the development and life of society.

But, despite all of the above, without the infusion of foreign donor investments, the country cannot yet develop independently, and foreign donors represented by large financial international organizations are pleased with this situation: the more we take loans, the more we depend on them. And we take a lot, and it is not only today's generation that has to pay off [12].

\section{Analysis of the state and servicing of public external debt}

From 2015 to 2017, there is a steady upward trend in the volume of the public external debt of the Kyrgyz Republic in US dollars. The decrease in external debt in 2018 was due to the write-off of the debt of the Kyrgyz Republic to the Russian Federation. The volume of public external debt in KGS equivalent depends on its impact on the US dollar exchange rate.

So, for example, the public external debt in US dollars at the end of 2019 increased compared to 2015 by $6.9 \%$, while in som equivalent, on the contrary, decreased by $2 \%$, which is associated with the strengthening of the national currency (if the end of 20151 US dollar $=75.9$ soms, then at the end of 20191 US dollar $=69.6$ soms).

As of December 31, 2019, the government debt of the Kyrgyz Republic amounted to USD 4,587.26 million (KGS 319,474.64 million), of which:

- $83.9 \%$ is public external debt: $3,850.73$

million US dollars (268,179.79 million soms);

- $16.1 \%$ is public internal debt: 736.53

USD million (KGS 51,294.85 million).

According to preliminary data, the ratio of the public external debt of the Kyrgyz Republic to GDP for 2019 was $45.5 \%$. Total public debt (external + internal) to GDP in 2019 amounted to $54.1 \%$ (Table 2-4).

There is also a tendency towards an increase in the cost of servicing the external state debt associated with the onset of maturity on many loans. So, in $2019,72.3 \%$ of the total cost of servicing the external state debt was directed to the repayment of the principal amount of the debt and accrued interest amounts of $27.7 \%$ [10].

Table 2. Trends in external debt, million soms

\begin{tabular}{|l|c|c|c|c|c|}
\hline \multicolumn{1}{|c|}{ Indicators } & $\mathbf{2 0 1 5}$ & $\mathbf{2 0 1 6}$ & $\mathbf{2 0 1 7}$ & $\mathbf{2 0 1 8}$ & $\mathbf{2 0 1 9}$ \\
\hline Public external debt & 273320 & 259110 & 281542 & 267229 & 268180 \\
\hline Receipt of loans & 20302 & 25743 & 24449 & 10412 & 13102 \\
\hline Debt repayment, including: & 7484 & 9180 & 9957 & 11943 & 14010 \\
\hline percent & 2827 & 3357 & 3470 & 3697 & 3878 \\
\hline principal amount & 4657 & 5823 & 6487 & 8246 & 10132 \\
\hline
\end{tabular}

Source: Ministry of Finance of the Kyrgyz Republic [10] 
Table 3. Trends in changes in external debt, USD million

\begin{tabular}{|l|c|c|c|c|c|}
\hline \multicolumn{1}{|c|}{ Indicators } & $\mathbf{2 0 1 5}$ & $\mathbf{2 0 1 6}$ & $\mathbf{2 0 1 7}$ & $\mathbf{2 0 1 8}$ & $\mathbf{2 0 1 9}$ \\
\hline Public external debt & $\mathbf{3 6 0 1 , 0}$ & $\mathbf{3} 742,7$ & 4089,8 & 3825,8 & 3850,7 \\
\hline Receipt of credits & 290 & 370 & 354 & 150 & 188 \\
\hline Debt repayment, including: & 130 & 145 & 144 & 185 & 201 \\
\hline Percent & 42 & 46 & 50 & 54 & 56 \\
\hline principal amount & 88 & 99 & 94 & 131 & 145 \\
\hline
\end{tabular}

Source: Ministry of Finance of the Kyrgyz Republic [10]

Table 4. Trends in debt sustainability indicators, public external debt to GDP, in\%

\begin{tabular}{|l|c|c|c|c|c|}
\hline \multicolumn{1}{|c|}{ Indicators } & $\mathbf{2 0 1 5}$ & $\mathbf{2 0 1 6}$ & $\mathbf{2 0 1 7}$ & $\mathbf{2 0 1 8}$ & $\mathbf{2 0 1 9}$ \\
\hline Public external debt & $63,5 \%$ & $54,4 \%$ & $53,1 \%$ & $46,9 \%$ & $45,5 \%$ \\
\hline Receipt of credits & $4,7 \%$ & $5,4 \%$ & $4,6 \%$ & $1,8 \%$ & $2,2 \%$ \\
\hline Debt repayment, including: & $1,1 \%$ & $1,9 \%$ & $1,9 \%$ & $2,1 \%$ & $2,4 \%$ \\
\hline Percent & $0,7 \%$ & $0,7 \%$ & $0,7 \%$ & $0,6 \%$ & $0,7 \%$ \\
\hline principal amount & $1,1 \%$ & $1,2 \%$ & $1,2 \%$ & $1,4 \%$ & $1,7 \%$ \\
\hline
\end{tabular}

Source: Ministry of Finance of the Kyrgyz Republic [10]

To reduce the level of public external debt, the Government of the Kyrgyz Republic in the period from 2015 to 2018. measures were taken with the Export-Import Bank of China and the Government of the Russian Federation to restructure the external state debt of the Kyrgyz Republic. As a result of the work done:

1) the debt of the Kyrgyz Republic to the Russian Federation has been entirely written off;

2) the debt of the Kyrgyz Republic was restructured to the construction project of the Paper Mill dated April 12, 2001.

In September 2018, the Government of the Kyrgyz Republic announced that "significant funds" about $20 \%$ of the budget - would be allocated annually to pay off debts (Table 5-6).

The main reason for the deviation of the actual costs of servicing the external state debt over the forecast indicators was the negative difference between the accrued liabilities and the forecast amounts of servicing existing loans approved by the republican budget (Table 7).

\section{Financial conditions of external credits provided.}

The currency structure of payments on the public external debt in 2017-2019 is presented in Table 8.

In 2017-20198, over $85 \%$ of all payments were made in US dollars. Both loans denominated in this currency and loans denominated in conditional fee (SDR, Islamic dinar) are serviced in US dollars. In 2019 , about $78 \%$ of all payments were made in US dollars. In the reporting period, both loans denominated in this currency and loans denominated in Kuwaiti dinars, Chinese yuan, UAE dirhams, Saudi riyals and denominated in conditional means of payment (SDR, Islamic dinar) were serviced in US dollars. 
Table 5. Expenses for servicing public debt, million soms

\begin{tabular}{|c|c|c|c|c|c|c|c|}
\hline Costs & $\begin{array}{c}\text { 2017, Nov } \\
\text { (fact) }\end{array}$ & $\begin{array}{l}\text { 2018, Oct } \\
\text { (plan) }\end{array}$ & $\begin{array}{c}\text { 2018, Oct } \\
\text { (fact) }\end{array}$ & $\begin{array}{c}\text { Deviatio } \\
n\end{array}$ & $\begin{array}{l}2019 \\
\text { (Plan) }\end{array}$ & $\begin{array}{l}2019 \\
\text { (Fact) }\end{array}$ & Deviation \\
\hline Percent & 5867,2 & 6980,3 & 7082,8 & 102,5 & 8048,1 & 7911,9 & $-136,2$ \\
\hline Domestic debt & 2397,5 & 2671,4 & 3385,5 & 714,1 & 3762,4 & 4033,5 & 271,1 \\
\hline External debt & 3469,7 & 4308,9 & 3697,3 & $-611,6$ & 4285,7 & 3878,4 & $-407,3$ \\
\hline Principal amount & 14753,3 & 18612,6 & 16664,9 & $-1947,7$ & 20278,9 & 20210,8 & $-68,1$ \\
\hline Domestic debt & 8265,8 & 9840,3 & 8419,4 & $-1420,9$ & 9898,4 & 10078,9 & 180,5 \\
\hline External debt & 6487,5 & 8772,3 & 8245,5 & $-526,8$ & 10380,5 & 10131,9 & $-248,6$ \\
\hline Total & 20620,5 & 25592,9 & 23747,7 & $-1845,2$ & 28327,0 & 28122,7 & $-204,3$ \\
\hline
\end{tabular}

Source: Ministry of Finance of the Kyrgyz Republic [10]

Table 6. Foreign loan servicing costs, million soms

\begin{tabular}{|c|c|c|c|c|c|c|c|}
\hline Costs & $\begin{array}{c}\text { 2017, Nov } \\
\text { (fact) }\end{array}$ & $\begin{array}{c}2018, \text { Oct } \\
\text { (plan) }\end{array}$ & $\begin{array}{c}2018, \text { Oct } \\
\text { (fact) }\end{array}$ & Deviation & $\begin{array}{c}2019 \\
\text { (Plan) }\end{array}$ & $\begin{array}{l}2019 \\
\text { (Fact) }\end{array}$ & Deviation \\
\hline Percent & 3469,7 & 4308,9 & 3697,3 & $-611,6$ & 4285,7 & 3878,4 & $-407,3$ \\
\hline \begin{tabular}{|l|} 
Bilateral \\
credits
\end{tabular} & 2570,9 & 3045,3 & 2735,7 & $-309,6$ & 3079,9 & 2780,0 & $-299,9$ \\
\hline $\begin{array}{l}\text { Multilateral } \\
\text { credits }\end{array}$ & 898,8 & 1263,6 & 961,6 & $-302,0$ & 1205,8 & 1098,4 & $-107,4$ \\
\hline Principal amount & 6487,5 & 8772,3 & 8245,5 & $-526,8$ & 10380,5 & 10131,9 & $-248,6$ \\
\hline Bilateral credits & 1738,7 & 2756,3 & 2626,1 & $-130,2$ & 3822,2 & 3799,4 & $-22,8$ \\
\hline $\begin{array}{l}\text { Multilateral } \\
\text { credits }\end{array}$ & 4748,8 & 6016,0 & 5619,4 & $-396,6$ & 6558,3 & 6332,5 & $-225,8$ \\
\hline Total & 9957,2 & 13081,2 & 11942,8 & $-1138,4$ & 14666,2 & 14010,3 & $-655,9$ \\
\hline
\end{tabular}

Source: Ministry of Finance of the Kyrgyz Republic [10]

The remainder of the operations is split between the euro, Japanese yen, Kuwaiti dinar, Korean won, Chinese yuan, UAE dirham and Saudi riyal. In addition, in servicing the external state debt, transactions in Kyrgyz soms took place. These transactions were carried out to correct the exchange rate difference in payments in foreign currency (refund to the accounts of the Central Treasury of the Ministry of Finance of the Kyrgyz Republic or an additional fee towards the NBKR when the exchange rate difference was formed).

Below are typical financial terms of external loans provided to the Kyrgyz Republic (Table 9).

The decrease in the volume of external debt in 2018 is associated with a reduction in the rate of disbursement of funds on external loans and the write-off of the debt of the Kyrgyz Republic to the Russian Federation of \$ 240 million.

To reduce the level of public external debt, the Government of the Kyrgyz Republic in the period from 2015 to 2018. the following activities were carried out:

- On May 18, 2015, a Supplementary Agreement was signed with the Export-Import Bank of China to the State Concessional Loan Agreement for the Paper Mill Construction Project dated April 12, 2001, according to which the principal amount of the loan, equal to RMB 60.2 million, is repayable in five equal semi-annual payments until June 20, 2017. It also provides for the settlement of technical debt on accrued interest, which in September 2014 amounted to 14.2 million Chinese yuan. In 
particular, RMB 10.1 million will be deducted from this amount. The remainder of the technical debt of RMB 4.1 million is due in five equal installments by June 20, 2017, without any interest charged;

Table 7. Structure of actual payments on public external debt for 2017-2019, million soms

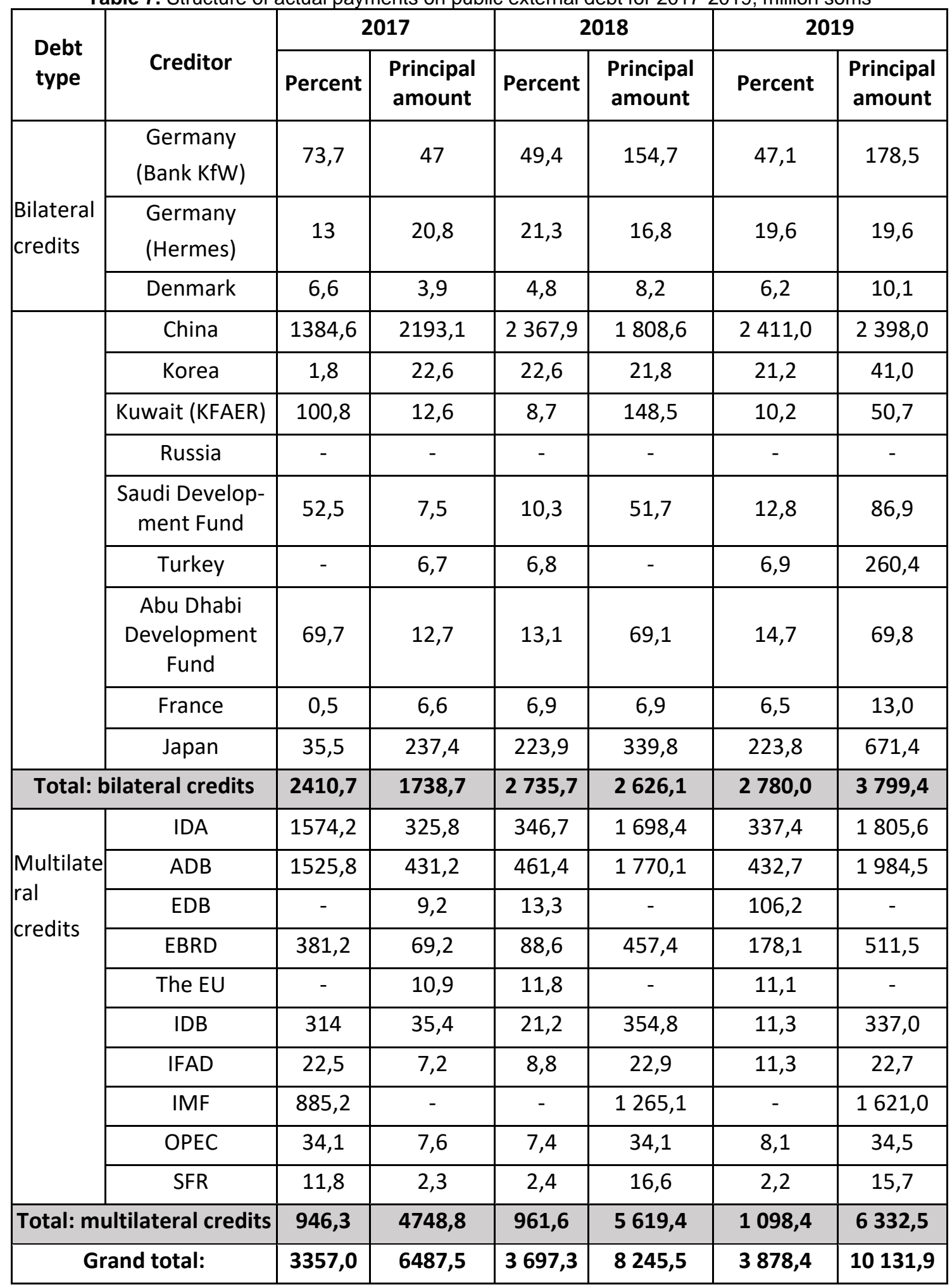

Source: Ministry of Finance of the Kyrgyz Republic [10]

- in 2016, the first US $\$ 30$ million was written off from the Government of the Russian Federation;

- in April 2016, within the framework of the Debt Conversion II and III project, the debt to the Federal Republic of Germany of EUR 13.5 million was written off;

- in 2017, an additional \$ 30 million was written off to the Government of the Russian Federation; 
- On February 22, 2018, the Protocol to the Agreement between the Government of the Kyrgyz Republic and the Government of the Russian Federation on the settlement of the debt of the Kyrgyz Republic to the Russian Federation on previously granted loans of September 20, 2012, signed in Moscow (Russian Federation) on June 20, 2017, entered into force. According to this Protocol, the debt of the Kyrgyz Republic to the Russian Federation of USD 240 million was written off at a time.

Table 8. Currency structure of payments on public external debt in 2017-2019, million soms

\begin{tabular}{|c|c|c|c|}
\hline Currency & $\mathbf{2 0 1 7}$ & $\mathbf{2 0 1 8}$ & $\mathbf{2 0 1 9}$ \\
\hline AED & 83,0 & 82,3 & - \\
\hline CNY & 133,7 & 110,9 & 631,2 \\
\hline EUR & 364,6 & 559,4 & 920,9 \\
\hline JPY & 280,1 & 580,6 & 64,0 \\
\hline KRW & 24,5 & 45,9 & - \\
\hline KWD & 114,6 & 157,1 & - \\
\hline SAR & 60,5 & 62,0 & 10860,3 \\
\hline USD & 8946,4 & 10383,3 & 1669,7 \\
\hline XDR & - & - & $-135,8$ \\
\hline KGS & $-50,2$ & $-38,7$ & 14010,3 \\
\hline Total & 9957,2 & 11942,8 & \\
\hline
\end{tabular}

Source: Ministry of Finance of the Kyrgyz Republic [10]

Table 9. Financial conditions for external loans

\begin{tabular}{|c|c|c|c|c|c|c|}
\hline Creditor & Currency & $\begin{array}{c}\text { Credit term } \\
\text { years }\end{array}$ & $\begin{array}{c}\text { Grace } \\
\text { period } \\
\text { years }\end{array}$ & $\%$ rate & $\begin{array}{l}\text { Obligati } \\
\text { on fee }\end{array}$ & $\begin{array}{l}\text { One-time } \\
\text { fee }\end{array}$ \\
\hline China & $\begin{array}{c}\text { US dollar, } \\
\text { Chinese yuan }\end{array}$ & $20-25$ & $5-11$ & $1,5 \%-2 \%$ & $\begin{array}{c}0,18 \%- \\
0,25 \%\end{array}$ & $\begin{array}{c}0,18 \%- \\
0,25 \%\end{array}$ \\
\hline France & Euro & 40 & 13 & $2 \%$ & - & - \\
\hline Japan & Japanese yen & 40 & $10-13$ & $0,1 \%-1,8 \%$ & - & $0,2 \%$ \\
\hline Germany (KfV) & Euro & 40 & $10-13$ & $0,75 \%-1,15 \%$ & $0,25 \%$ & - \\
\hline $\begin{array}{l}\text { Germany } \\
\text { (Hermes) }\end{array}$ & Euro & 23 & 7 & $5 \%$ & - & - \\
\hline Korea & korean won & 40 & 13 & $2 \%$ & - & - \\
\hline Kuwait & Kuwaiti dinar & $24-26$ & 4 & $1,5 \%-2 \%$ & - & - \\
\hline Saudi Arabia & Saudi riyal & 25 & 5 & $1 \%$ & - & - \\
\hline Turkey & U.S. dollar & 20 & 7 & $0,1 \%$ & - & - \\
\hline UAE & UAE dirham & 20 & 5 & $2,5 \%$ & - & - \\
\hline Denmark & U.S. dollar & 23 & 7 & LIBOR+0,5\% & - & - \\
\hline IMF & (XDR) & 10 & 5 & $0,5 \%$ & - & - \\
\hline OPEC & U.S. dollar & 17 & 5 & $2,25 \%$ & - & - \\
\hline ADB & $\begin{array}{c}\text { (XDR), } \\
\text { U.S. dollar }\end{array}$ & $24-40$ & $8-10$ & $1 \%-1,5 \%$ & - & - \\
\hline EDB & U.S. dollar & 20 & 8 & $1 \%$ & $0,5 \%$ & $0,5 \%$ \\
\hline
\end{tabular}




\begin{tabular}{|l|c|c|c|c|c|c|}
\hline The EU & Euro & 15 & 14 & $0,75 \%-1,375 \%$ & - & - \\
\hline IDA (WB) & (XDR) & $38-40$ & $6-10$ & $0,75 \%$ & - & - \\
\hline IDB & $\begin{array}{c}\text { Islamic dinar, } \\
\text { US dollar }\end{array}$ & $25-30$ & $7-10$ & $\begin{array}{c}\text { less than } \\
0,75 \%-02,5 \%\end{array}$ & - & - \\
\hline IFAD & (XDR) & 40 & 10 & $0,75 \%$ & - & - \\
\hline SFR & Euro & 40 & 10 & $0,75 \%$ & - & - \\
\hline EBRD & $\begin{array}{c}\text { euro, } \\
\text { US dollar }\end{array}$ & 15 & 3 & $\begin{array}{c}\text { EURIBOR } \\
+1 \%, \text { LIBOR+1\% }\end{array}$ & $0,5 \%$ & $1 \%$ \\
\hline
\end{tabular}

Source: Ministry of Finance of the Kyrgyz Republic [10]

\section{Macroeconomic effect of external debt.}

It is planned to spend on servicing the external state debt of the Kyrgyz Republic: in $2021-19,999$ million soms, in 2022 - 23,728 million soms, in 2023 - 29,973 million soms (Table 10-11).

Table 10. Current debt, receipts and repayment of external loans, in a million soms

\begin{tabular}{|l|c|c|c|c|}
\hline \multicolumn{1}{|c|}{ Indicators } & $\mathbf{2 0 2 0}$ & $\begin{array}{c}\mathbf{2 0 2 1} \\
\text { forecast }\end{array}$ & $\begin{array}{c}\mathbf{2 0 2 2} \\
\text { forecast }\end{array}$ & $\begin{array}{c}\mathbf{2 0 2 3} \\
\text { forecast }\end{array}$ \\
\hline External debt (at the end of the year) & 348485 & 347209 & 357759 & 361694 \\
\hline Receipt of loans ** & 51594 & 21227 & 21790 & 21189 \\
\hline Debt repayment, including: & 18111 & 19999 & 23728 & 29973 \\
\hline percent & 4998 & 5001 & 5134 & 5144 \\
\hline principal amount & 13113 & 14998 & 18594 & 24829 \\
\hline
\end{tabular}

Source: Ministry of Finance of the Kyrgyz Republic [10]

Table 11. Current debt, inflow and repayment of external loans, in \% of GDP

\begin{tabular}{|l|c|c|c|c|}
\hline \multicolumn{1}{|c|}{ Indicators } & $\mathbf{2 0 2 0}$ & $\begin{array}{c}\mathbf{2 0 2 1} \\
\text { forecast }\end{array}$ & $\begin{array}{c}\mathbf{2 0 2 2} \\
\text { forecast }\end{array}$ & $\begin{array}{c}\mathbf{2 0 2 3} \\
\text { forecast }\end{array}$ \\
\hline External debt & $59,8 \%$ & $54,7 \%$ & $51,7 \%$ & $50,0 \%$ \\
\hline Debt repayment, including: & $3,1 \%$ & $3,2 \%$ & $3,4 \%$ & $4,1 \%$ \\
\hline percent & $0,9 \%$ & $0,8 \%$ & $0,7 \%$ & $0,7 \%$ \\
\hline principal amount & $2,2 \%$ & $2,4 \%$ & $2,7 \%$ & $3,4 \%$ \\
\hline
\end{tabular}

Source: Ministry of Finance of the Kyrgyz Republic [10]

The budget for servicing the public external debt of the Kyrgyz Republic for 2021 and the forecast for 2022-2023 has been drawn up, taking into account the work carried out by the Government of the Kyrgyz Republic aimed at ensuring strict discipline in attracting and spending foreign loans, commensurate with the following targets [10]:

1) prevention of delinquencies in payments on repayment of the external state debt of the Kyrgyz Republic (except technical delays that arise in the course of the negotiation process to conclude agreements on the restructuring of bilateral debt);

2) maintaining $35 \%$ of the minimum level of preferential treatment for new external borrowing and prohibiting local government bodies from attracting external loans without the appropriate permission of the Ministry of Finance of the Kyrgyz Republic;

3 ) adherence to the quantitative and qualitative requirements of the public investment program in the process of implementing new external borrowings.

When compiling a medium-term budget forecast, the following initial data were taken into account:

1) the amount of disbursed and outstanding public external debt as of December 31, 2019, which amounted to 268.2 billion soms [10];

2) repayment schedules for existing and planned loans; 
3) forecast of the disbursement of credit funds for existing and planned external borrowings;

4) forecast exchange rates of foreign currencies against the US dollar, calculated according to the IMF data based on actual rates from November 2019 to May 2020.

Table 12 reflects the prevalence of the trend of external net borrowings in the total volume of borrowings. The volume of public external debt is more than $90 \%$ of the total volume of public debt.

Table 12. Comparative analysis of external and internal debt

\begin{tabular}{|l|c|c|c|c|}
\hline \multicolumn{1}{|c|}{ Indicators } & $\mathbf{2 0 1 5}$ & $\mathbf{2 0 1 6}$ & $\mathbf{2 0 1 7}$ & $\mathbf{2 0 1 8}$ \\
\hline $\begin{array}{l}\text { Net domestic borrowings as\% of net total } \\
\text { borrowings }\end{array}$ & $12,4 \%$ & $-0,5 \%$ & $13,7 \%$ & $63,8 \%$ \\
\hline $\begin{array}{l}\text { Net external borrowings as\% of net total } \\
\text { borrowings }\end{array}$ & $87,6 \%$ & $100,5 \%$ & $86,3 \%$ & $36,2 \%$ \\
\hline Net Total Borrowings (KGS) & 21007 & 30862 & 30950 & 28760 \\
\hline Internal debt as a\% of total debt & $5,4 \%$ & $5,2 \%$ & $5,9 \%$ & $14,3 \%$ \\
\hline External debt as\% of total debt & $94,6 \%$ & $94,8 \%$ & $94,1 \%$ & $85,7 \%$ \\
\hline Total debt & 288804 & 317942 & 348275 & 311835 \\
\hline
\end{tabular}

Source: Ministry of Finance of the Kyrgyz Republic [10]

During the period under review, about $87 \%$ of all payments were made in US dollars. Both loans denominated in this currency and loans denominated in conditional fee (SDR, Islamic dinar) are serviced in US dollars. The remainder of the operations is split between the Euro, Japanese Yen, Kuwaiti Dinar, Korean Won, Chinese Yuan, UAE Dirham and Saudi Riyal. In addition, in servicing the external state debt, transactions in Kyrgyz soms took place. These transactions were carried out to correct the exchange rate difference in payments in foreign currency (refund to the accounts of the Central Treasury of the Ministry of Finance of the Kyrgyz Republic or an additional fee towards the National Bank of the Kyrgyz Republic when the exchange rate difference was formed) [10].

As shown from the above table 13, the volume of attracting external loans exceeds the amount to repay liabilities on external loans. It will lead to the fact that the volume of public external debt in 2021-2023 in the nominal volume will increase. Also, due to the maturity of the principal amounts of borrowed loans, there is an annual increase in the cost of repaying the principal amount on loans.

In the forecast period, the prevalence of external borrowings in the total volume of borrowings is reflected. The volume of public external debt is more than $80 \%$ of the total volume of public debt.

\section{Discussion.}

The current problems of the growth of public external debt are endless problems with a lack of domestic resources, poor economic development, and inadequate public management concerning the country's external debt. Consider the chronology of the reasons for the growth of public external debt [13].

Table 13. Forecast of external and internal debt

\begin{tabular}{|l|c|c|c|c|c|c|}
\hline \multicolumn{1}{|c|}{ Indicators } & $\mathbf{2 0 1 8}$ & $\mathbf{2 0 1 9}$ & $\mathbf{2 0 2 0}$ & $\begin{array}{c}\mathbf{2 0 2 1} \\
\text { forecast }\end{array}$ & $\begin{array}{c}\mathbf{2 0 2 2} \\
\text { forecast }\end{array}$ & $\begin{array}{c}\mathbf{2 0 2 3} \\
\text { forecast }\end{array}$ \\
\hline $\begin{array}{l}\text { Internal borrowing as a \% of total } \\
\text { borrowings }\end{array}$ & $63,8 \%$ & $53,2 \%$ & $23,0 \%$ & $42,0 \%$ & $41,4 \%$ & $42,1 \%$ \\
\hline $\begin{array}{l}\text { External borrowings in\% of total } \\
\text { borrowings }\end{array}$ & $36,2 \%$ & $46,8 \%$ & $77,0 \%$ & $58,0 \%$ & $58,6 \%$ & $57,9 \%$ \\
\hline Total borrowings (million soms) & 28760 & 27994 & 66994 & 36627 & 37190 & 36589 \\
\hline Internal debt as a\% of total debt & $14,3 \%$ & $16,1 \%$ & $14,6 \%$ & $16,5 \%$ & $18,3 \%$ & $20,1 \%$ \\
\hline External debt as\% of total debt & $85,7 \%$ & $83,9 \%$ & $85,4 \%$ & $83,5 \%$ & $81,7 \%$ & $79,9 \%$ \\
\hline Total size of all debt (million soms) & 311835 & 319475 & 408189 & 415679 & 437942 & 452726 \\
\hline
\end{tabular}


From 2008 to the present, it has become indicative, both in terms of the importance of effective and balanced government debt management and the Kyrgyz Republic's exposure to risks associated with government borrowing. The total effect of measures to reduce and curb the growth of public external debt (comprehensive restructuring of bilateral debt within the framework of the Paris Club, the introduction of restrictions on concessions for new external borrowing) demonstrated the example of 2008 when the amount of public debt of the Kyrgyz Republic amounted to 49\% of GDP. This indicator is the lowest for the period from 1995 to 2011. This ratio is partly due to the high nominal GDP growth in 2008 (about 32\%). However, this circumstance in no way diminishes the importance of effective public debt management. As follows from experience, the Kyrgyz Republic had a higher level of public debt, despite the very dynamic growth of the gross domestic product.

Along with advances in public debt management, the experience of 2008-2011 also highlighted the extent to which the Kyrgyz Republic remains dependent on public borrowing and sensitive to public debt risks [12].

Crisis processes in the world economy in 2008-2009, significant needs for financing the state budget, and events within the republic in 2010 led to the need for active accumulation of public debt. In 2009, the nominal amount growth of public debt amounted to $29 \%$, which was the highest for the period from 2000 to 2011. The ratio of public debt to GDP in 2009 was $60 \%$ (against $49 \%$ in 2008). The increase in the size of public debt was due to the attraction of large loans from the Russian Federation and the People's Republic of China for the development of the energy sector and transport infrastructure and a very noticeable devaluation of the Kyrgyz som [13].

In 2011, the amount of public external debt increased compared to 2010 by USD 186.9 million in nominal terms, or by $3.2 \%$ concerning GDP. The external debt increase in 2011 was also due to the state budget deficit's growth due to political and socio-economic instability due to the events in the country in April-June 2010. However, the adverse events that occurred in 2008-2010 were then exacerbated by the situation of Covid-19, for the fight against which foreign loans were again attracted.

Given that Kyrgyzstan is a low-income country, the World Bank and the International Monetary Fund believe that Kyrgyzstan is in a good position in debt sustainability criteria.

An indicator of debt sustainability for the Kyrgyz Republic with its level of institutional development is about $40 \%$ of GDP at present value. But today, this indicator is already approaching a very critical level $-60 \%$ of GDP.

Kyrgyzstan belongs to the low or moderate group since its external borrowings are mainly concessional loans. However, it should be noted that, despite the positive assessment of the debt sustainability of the Kyrgyz Republic by the World Bank and the International Monetary Fund, there are certain problems in the area of external debt management.

\subsection{The main problems of external debt regulation.}

Rapid growth and high share of external loans in the total public debt. In the structure of the public debt of the Kyrgyz Republic, the percentage of external debt remains dominant.

External debt increased from $\$ 5.0$ million in 1992 to $\$ 4,587.3$ billion in 2019. In the structure of the public debt of the Kyrgyz Republic, the share of external debt was $83.9 \%$, the percentage of domestic loans was $16.05 \%$.

The primary sources of interest and principal payments on foreign loans are budget funds, debt cancellation, and debt exchange for assets. The critical advantage of external borrowing for the Kyrgyz Republic is access to concessional financial resources provided by international financial institutions (World Bank, regional development banks and others) and foreign countries within the framework of official development assistance. At the same time, the prevalence of external financing in the structure of public debt indicates a high degree of dependence of the Kyrgyz Republic on external loans. 


\subsection{The problem of financial stability in Kyrgyzstan.}

The growth of the external debt of Kyrgyzstan and the instability of the dollar exchange rate may reduce the financial stability of the republic. Problems in the banking and non-banking sectors related to lending are reflected in the financial stability of the banking sector and the economy of Kyrgyzstan as a whole.

\subsection{Growth of China's share in the total volume of bilateral concessional loans.}

Recently, there has been uneven growth in the share of bilateral loans in the structure of external debt. Today, China is the main creditor for bilateral concessional loans. Its share in the total volume of bilateral concessional loans is $79.9 \%$, the rest of the loans are distributed between the creditor countries Japan, Germany and Turkey. 45 percent of the $\$ 3.8$ billion of Kyrgyzstan's external debt was received from the PRC - and this is no less than $\$ 1.7$ billion [10].

There are positive aspects of foreign lenders and investors. They come to Kyrgyzstan with investments. The advantages are colossal. In addition to investment capital, they bring new technologies, new products, know-how, etc. The multiplier effect is noticeable.

The negative side is that the foreign creditor-investor claims to be co-management, part of the company, profit, etc.

\subsection{Limiting opportunities for expanding external debt diversification.}

The growth of bilateral borrowing impedes proper diversification of the borrowing portfolio, which entails an increase in the risk of debt repayment. This issue for Kyrgyzstan is becoming critical in light of the high rates of external borrowing over the past few years.

\subsection{The problem of public debt sustainability.}

The Ministry of Finance of the Kyrgyz Republic believes that the forecast of the debt situation in the Kyrgyz Republic is stable but remains subject to the negative impact of significant external shocks. Events associated with a sharp fluctuation in the dollar's exchange rate in 2014 and early 2015 led to the fact that the external debt of the republic increased by 30 billion soms.

Nevertheless, the analysis of the state and trends in the development of public external debt showed other problems.

All these years, Kyrgyzstan has paid only interest on foreign loans, but today the time has come for Kyrgyzstan to pay the primary debt on preferential loans. From 2023 to 2031, Kyrgyzstan will need more funds to pay off the public debt. And in 2027, these payments will reach a peak - they will amount to $\$ 400$ million in external debt alone. Recall that in 2019 , half of this amount was paid on domestic debts and half as servicing external debt. $\$ 400$ million must be paid in 2027 [10].

If Kyrgyzstan stops increasing its external obligations, then the country will fully pay off loans by 2050.

\section{Conclusion.}

The presence of a vast and criminally consumed external debt for our republic can, in the end, lead to the loss of sovereignty since donors, anticipating loans, set specific requirements of both economic and political nature. As the republic will continue to sink into debt every year, political pressure on the Kyrgyz government will intensify.

To date, the foreign borrowing policy of the Kyrgyz Republic is based mainly on concessional loans from international financial organizations and donor countries and the so-called political loans, the purpose of which is not financial, but rather political results.

In general, if the corresponding growth in GDP and exports is not achieved, and a set of measures is not taken to improve the debt situation in the republic, then the debt burden for 2019-2025 will, in 
turn, divert significant funds from economic growth, rendering social assistance and overall poverty reduction strategy, i.e., the country will be in the category of countries with the highest external debt burden [10].

The onerousness of public debt and the imposition of conditions in its formation lead to the fact that in current conditions, countries are trying to move from a policy of deficit financing to a deficitfree budget. The new budgetary policy finds expression in changes in the revenue side of state budgets, stimulation of investment activity, and expansion of the tax base due to the growth of revenues and profitability of the national economy.

In general, summarizing the above, we note that public debt problems affect a wide range of socio-economic consequences of internal and external borrowing, both in the short and long term.

\section{References}

1. Enhancing the prospects for growth and trade of the Kyrgyz Republic. (2005). World Bank Country Study, pp. 1-180.

2. Mitra, P.K. (2010). The Impact of Global Financial Crisis and Policy Responses: The Caucasus, Central Asia and Mongolia. Global Journal of Emerging Market Economies, 2(2), pp. 189-230.

3. Omurova, J.O. (2019). Cooperation of the kyrgyz republic with the Chinese people's republic within the framework of the "one belt - one way" project. Vestnik Volgogradskogo Gosudarstvennogo Universiteta, Seriia 4: Istoriia, Regionovedenie, Mezhdunarodnye Otnosheniia, 24(5), pp. 236-249.

4. National Statistical Committee of the Kyrgyz Republic. www.stat.kg

5. Gurgen, E., Snoek, H., Craig, J., McHugh, J., Izvorski, I., van Rooden, R. (1999). Economic reforms in Kazakhstan, Kyrgyz Republic, Tajikistan, Turkmenistan, and Uzbekistan. IMF Occasional Papers, 183, pp. 1-77.

6. Beyer, J. (2006). Revitalisation, invention and continued existence of the kyrgyz aksakal courts: Listening to pluralistic accounts of history. Journal of Legal Pluralism and Unofficial Law, 38(5354), pp. 141-176.

7. Schuler, M. (2007). Migration patterns of the population in Kyrgyzstan. Espace-PopulationsSocietes, 1, pp. 73-89.

8. Toktosunova Ch.T. Features of distribution and succession in relation to the external public debt and assets of the USSR. https://www.elibrary.ru/item.asp?id=26549800

9. Chenoy, A.M. (1997). Political and economic processes in the Central Asian Republics. International Studies, 34 (3), pp. 301-312.

10.Ministry of Finance of the Kyrgyz Republic. www.minfin.kg

11.Toktosunova Ch.T. The current state of the public debt of the Kyrgyz Republic. https://www.elibrary.ru/item.asp?id=27811362

12.Toktosunova Ch.T. Dependence of the national economy on the growth of public debt. https://www.elibrary.ru/item.asp?id=30304792

13.Toktosunova Ch.T. Using world experience in public debt management. https://www.elibrary.ru/item.asp?id=37211455 